\title{
On-Task and Off-Task Self-Assessment: Which Works Better on Young Learners' Writing Performance?
}

\author{
Ni Luh Putu Eka Sulistia Dewi ${ }^{1 *}$, I Nyoman Pradnyana Bayu Trisna ${ }^{2}$ iD \\ 1,2,3 Universitas Pendidikan Ganesha, Singaraja, Indonesia \\ *Corresponding author: sulistia.dewi@undiksha.ac.id
}

\begin{abstract}
The implementation of self-assessment might contribute to the young learners' English proficiency and affective domain. Yet, there is still limited findings found for the effect on young learners' writing performance. This experimental study investigated the effect of on-task and off-task self-assessment on young learners of English as a foreign language in Bali, Indonesia. 46 sixth graders participated in this study were required to do self-assessment in completing their writing prompt. A self-assessment checklist was used as the instrument. The on-task self-assessment group applies the self-assessment checklist at every stage of their writing process, namely pre-writing, drafting, revising, editing, and publishing. On the other hand, the off-task self-assessment group uses the self-assessment checklist before they start the writing process. Using independent samples t-test for hypothesis testing, it was found that there is no significant difference in both groups' writing performance since the real probability that is due to sampling error is .194 which is bigger than the significance level of .05 . Therefore, self-assessment could be implemented in on-task and off-task since it brings similar effect to the young learners' writing performance.
\end{abstract}

Keywords: Self-Assessment, On-Task Self-Assessment, Off-Task Self-Assessment, Young Learners, Writing

\begin{tabular}{|c|c|c|}
\hline History: & & Publisher: Undiksha Press \\
\hline Received & : August 09, 2021 & Licensed: This work is licensed under \\
\hline Revised & : August 10, 2021 & a Creative Commons Attribution 3.0 License \\
\hline Accepted & : September 17, 2021 & (c) (†) () \\
\hline Published & : October 25, 2021 & $\mathrm{EY}_{\mathrm{BA}}$ \\
\hline
\end{tabular}

\section{INTRODUCTION}

Writing is considered as a complex skill not only in the students' mother tongue or first language, but also in English as a foreign language. The complexity might be caused by the involvement of not only cognitive aspect but also linguistics skills of the writer which involves thinking process (Brown \& Lee, 2015; Graves et al., 2004). A writer should learn to think and go through the thinking process before producing the final product. He or she should make decision on the most valuable parts on the writing pieces and engage in the revision process to create what is called by Graves as "ownership" that might increase commitment and willingness to take responsibility for the writing. This process may vary from day to day and involves highly idiosyncratic process. Therefore, assessment method which could capture the student's individual writing development and showcase the writing progress over time is required, and it could take the form of assessment as learning.

Assessment as learning is an ongoing assessment. It focuses on student's individual performance which could be promoted through self-assessment (Dann, 2012; Earl, 2013). It gives students opportunity to monitor their own learning which is "characterized by students reflecting on their own learning and making adjustments so that they achieve deeper understanding" (Earl \& Katz, 2006; Schraw, 1998). It would involve the metacognition process that is "thinking about one's own mental process" or the "regulation of cognition" (Schraw, 1998) which might indicate what the students know and what they do not know. In accordance with writing process, self-assessment will help learners come to understand themselves more, and find how to work through the writing. They may explore what strategies conform to their style of learning. For this case, self-assessment gives the students 
opportunity to be involved on the assessment process not only for the writing process but also it finally would help students to predict their writing performance (Schulz, 2009). Although some research had found that self-assessment works best for more advanced or adult English learners, some studies have shown different results. Self-assess appear to improve as young learners are around age 8-12, and their continuous involvement on the exercise of implementing self-assessment made them able to assess themselves more accurately (Butler \& Lee, 2006; Paris \& Paris, 2001). As a result, they become more aware of their strengths and weaknesses, and at the same time they could consider some efforts to overcome their learning problem. Therefore, self-assessment is suggested to be applied to students starting from the $5^{\text {th }}$ grade (10-11 years old) when they initially recognize the important of learning.

The implementation of self-assessment is often considered "subjective", but it was discovered that self-assessment which is conducted in contextualized manner might be more valid for assessing the young learners' language performance compared with the decontextualized self-assessment (Butler \& Lee, 2006). Contextualized manner of selfassessment refers to on-task self-assessment while the decontextualized one refers too offtask self-assessment. Off-task self-assessment asks students to evaluate their overall performance in general before the instruction takes place. Conversely, on-task selfassessment asks the students to do the evaluation on their performance immediately after they completed their task. Conducting self-assessment in an on-task format could also yield other advantages for the students. The students might have a better chance of being prepared for the instruction ( Butler \& Lee, 2006; Butler, 2009; Butler \& Lee, 2010; Y. Suzuki, 2015). However, no discussion has addressed on the effect of both on-task and off-task selfassessments affect the students' English performance. The young learners' ability to assess themselves might bring positive effects on their affective domain as well as their English language skills. Self-assessment might affect young learners' motivation, confidence, and anxiety (Yoon \& Lee, 2013), and it might move from being 'other-regulated' to being 'selfregulated' (Cameron, 2010; Carless, 2005). Moreover, self-assessment could positively affect the learners' self-efficacy which later might contribute to the improvement of the language skills (Baleghizadeh \& Masoun, 2013; Johnson \& Gelfand, 2013; Le'ger, 2009; Shahrakipour, 2014; Y. Suzuki, 2015).

In terms of writing, most of research findings reported the effect of self-assessment on more adult learners. Self-assessment was found to be able to improve the secondary school and university students' writing quality (H. Andrade \& du, 2007; Birjandi \& Tamjid, 2012; Johnson \& Gelfand, 2013). It was found that the improvement was affected by the ability of the students in critically judge their writing draft using rubric as guidance for their selfassessment (H. G. Andrade \& Boulay, 2003). It was also found that those who received selfassessment and teacher feedback displayed statistically significant better improvement in writing performance compared with those receiving teacher feedback only (Birjandi \& Tamjid, 2012). It indicates that self-assessment takes important role on writing performance. Since providing context into self-assessment implementation has already been proven to be more accurate than decontextualized one, but report on its' effect on young learners' writing performance is still limited, further investigation is needed to be conducted. For that reason, this paper is aimed at examining the effect of on-task and off-task self-assessment on young learners' writing performance. It is expected that the implementation of self-assessment for assessing young learners of English may lead young learners to be more autonomous learners that might be beneficial for developing the essentialism of lifelong learning. 


\section{METHODS}

This experimental study was conducted in two experimental groups; one group receives the experimental treatment using on-task self-assessment while the other group receives experimental treatment using off-task self-assessment. A pre-test was conducted to all populations: the 72 sixth grade students who were grouped in three classes. The scores from the three groups were compared using t-test to determine two groups of samples which statistically show significant similar writing performance. The computation of independent sample test shows there is no significant difference between group A and Group B ( $\mathrm{p}=.543$; p>.05). It indicates both groups (46 sample) have equal writing performance. The two equal groups, Groups A and B were then randomly selected as the experimental groups of the study through lottery. The result of the lottery showed that Group A became the experimental group 1 (On-task self-assessment group) and Group B became the experimental group 2 (Off-task self-assessment group). Before the treatment was conducted, consent forms ware distributed to the sample of the study to indicate permission from the parents.

Two kinds of instruments were used for the study, namely: instruments for data collection and instruments for the treatment. The instrument for data collection was writing prompt. The on-task and off-task self-assessment checklist were instruments used for the treatment. Indonesian was the language used to develop the instrument since it is the students' first language to maintain its validity. The writing prompts were empirically proven to be very good instruments. SPSS statistical package version 21 based on absolute agreement, two-way random-effect model, showed the result of the computation for the ontask self-assessment group that the reliability coefficient is .822 which is $>.70$. It indicates that both raters have high agreement on each student's score and the reliability is categorized as good. Meanwhile, the reliability coefficient for the group which used off-task selfassessment is .865 which is $>.70$ (Table 2.3.6). It also indicates that there is high agreement between both raters toward each student's score and it has good category of reliability. It could be concluded that the inter-rater reliability for both groups are high and categorized as good reliability, and as the consequence, the writing prompts were considered to be reliable and valid instruments for assessing young learners' writing performance

For the purpose of the study, the confirmatory factor analysis was conducted to all the 38 items on the self-assessment checklist that have been validated by the experts, and it involved 142 sixth graders as respondents from three different elementary schools. It was found that the KMO value is 0.623> .5. From the Anti-image matrices on Anti-image Correlation, it was found that there were 32 items with correlation coefficient $>.5$ and 4 items which correlation coefficient <.5, Therefore, the four items were considered as not valid items that must be dropped. As the consequence, 32 items were used to collect the data from the 36 items prepared. The data collected were analyzed through descriptive statistical analysis and inferential statistics analysis using SPSS statistical package version 21. The descriptive statistical analysis was conducted to analyze the data in term of central tendency and spread of dispersion in terms of the mean score and the standard deviation of the two groups. Meanwhile, the inferential statistical analysis was carried out by independent samples t-test with the significance level .05 .

\section{RESULTS AND DISCUSSION}

\section{Result}

\section{Descriptive Analysis Results}

The students' paragraphs were scored by two raters and the result was analysed in terms of its reliability. The result of the analysis shows the intra-class correlation coefficient (ICC) is 0.85 . Therefore, the scores can be analysed further into its descriptive analysis to 
compare the mean score of the experimental groups, on-task and off-task self-assessment groups, and to know the standard deviation. Table 1 summarizes the result of the descriptive analysis for the overall writing performance.

Table 1. The Result of the Descriptive Analysis for the Writing Performance

\begin{tabular}{cccc}
\hline Group & N & Mean & Standard Deviation \\
\hline Off Task & 23 & 75.0435 & 5.69272 \\
On Task & 23 & 72.7391 & 6.15126 \\
\hline
\end{tabular}

The mean score of off-task group (75.0435) is higher than on-task (72.7391). It means that the writing performance of the off-task students is better than on-task students. In terms of standard deviation, the standard deviation of off- task group (5.69272) is lower than ontask (6.15126). It means that the data of writing performance for on-task students is more various than off-task students. The hypothesis testing was conducted by using independent samples t- test. This formula was selected because 1) there were only two groups compared, 2) the number sample of each group was lower than 30, and 3) the group was intact group. Before the test was done, there are two prerequisite tests which should be fulfilled namely normality test of data distribution and homogeneity of variance test.

\section{Normality Test of Data Distribution}

Normality test is aimed at knowing whether or not the data is normally distributed. So, the result of hypothesis testing can be generalized from sample to population. This test was administered by using Kolmogorov-Smirnov. The data is considered normally distributed if the significance value is higher than 0.05 . The summary of the analysis is presented in Table 2. From Table 2, it is known that the normality of both groups is $0.2>0.05$. It means that the data from the sample are normally distributed.

Table 2. The Result of Normality Test

\begin{tabular}{lccccccc}
\hline & & \multicolumn{3}{c}{ Kolmogorov-Smirnov $^{\text {a }}$} & \multicolumn{3}{c}{ Shapiro-Wilk } \\
\cline { 3 - 8 } & Group & Statistic & Df & Sig. & Statistic & df & Sig. \\
\hline \multirow{2}{*}{ Score } & off task & 0.093 & 23 & 0.200 & 0.971 & 23 & 0.703 \\
& on task & 0.142 & 23 & 0.200 & 0.913 & 23 & 0.047 \\
\hline
\end{tabular}

\section{Homogeneity of Variance Test}

Homogeneity of variance test is aimed at testing the homogeneity of variance among groups so that it can be ensured that the difference occurred in t-test is caused by the difference among group, not difference within group. This test was done by using Levene test. The data is considered homogenous if the significance value of Based on Mean is higher than 0.05. The result of the analysis is presented in Table 3. Based on the Table 3, it is known that the significance value of Based on Mean is $0.516>0.05$. It means that the data is homogenous.

Table 3. Test of Homogeneity of Variance

\begin{tabular}{llcccc}
\hline & Levene Statistic & df1 & df2 & Sig. \\
\hline Score & Based on Mean & 0.429 & 1 & 44 & 0.516 \\
& Based on Median & 0.374 & 1 & 44 & 0.544 \\
$\begin{array}{l}\text { Based on Median and with } \\
\text { adjusted df }\end{array}$ & 0.374 & 1 & 43.999 & 0.544 \\
\hline
\end{tabular}




\begin{tabular}{llcccc}
\hline & Levene Statistic & df1 & df2 & Sig. \\
\hline Score & Based on Mean & 0.429 & 1 & 44 & 0.516 \\
& Based on Median & 0.374 & 1 & 44 & 0.544 \\
& $\begin{array}{l}\text { Based on Median and with } \\
\text { adjusted df }\end{array}$ & 0.374 & 1 & 43.999 & 0.544 \\
\cline { 2 - 6 } & Based on trimmed mean & 0.417 & 1 & 44 & 0.522 \\
\hline
\end{tabular}

\section{Independent Sample t-test}

To seek for the answer of the research question that is to know whether there is significant difference on young learners' writing performance in terms of their writing dimensions (content, organization, language use, mechanics and writing presentation) when they use on-task and off-task self-assessment, the independent sample t-test analysis was conducted. The result of hypothesis testing using independent samples t-test shows the real probability which is due to sampling error is .194 which is bigger than the significance value of .05. Therefore, the null hypothesis is supported. It means that there is no significant difference of mean scores between the both groups. It indicates that the on-task and off-task self-assessment bring similar effect to the young learners' writing performance.

\section{Discussion}

The use of on-task self-assessment was found to be more valid for assessing the young learners' English proficiency compared with the off-task self-assessment and it is relatively better predictor of students' performance (Butler \& Lee, 2006). The finding of this study shows that in spite of its validity, self-assessment brings similar effect on the young learners' writing performance either in on-task or off-task self-assessment. Young learners who already emerge their metacognitive skill at the age of 8 to 10 years, and still expanding during the year after seems like performing their ability in using the metacognition in similar way to accomplish the task. They actively engage in using the result of their reflection either before they start to write or while they are writing. They make decisions about the standards of performance expected and then making judgments about the quality of the performance in relation to these standards.

The ability of young learners in using their metacognitions to process information might affect their learning performance. It is relevant to finding which shows that metacognitive skilfulness becomes the primary factor of prediction toward young learners' learning performance (Birjandi \& Tamjid, 2012; Butler \& Lee, 2010). Therefore, the characteristic of the young learners in the age of 10 to 11 years who are still in the period of improving their metacognitions might confirm the Vygotskians assumptions that "children might have limited capacity to use language in order to guide self-regulation without the help of adults or more capable peers" (Birjandi \& Tamjid, 2012; Butler \& Lee, 2010). Both ontask and off-task self-assessment provides the young learners with the opportunities of making decisions for improvement and making judgment on the quality of the performance in their learning, in this study refers to writing process. It is relevant with description that learners critically and actively analyse their learning and reflection on their learning progress to guide new learning (Schulz, 2009). Therefore, self-assessment takes a part as assessment as learning and reflects the role of constructivist learning since learners construct their knowledge and meaning from their experiences as proposed by the constructivism theory. The characteristics of young learners who are still in their formal operational stage where they still experience the development of self-correction growth and metacognitive awareness might contribute to the result of the study. The young learners' self-awareness on their metacognition would be improved if self-assessment is implemented overtime in their 
learning process. As consequence, this regular basis of self-assessment implementation will affect the young learners' English performance.

The training sessions conducted as pre-experimental procedure might allow the young learners to familiarize themselves with the criteria of good paragraph writing, and by using self-assessment the young learners would try to make reflection on whether their paragraph has meet the criteria set since the self-assessment checklist items are in accordance with the criteria. In this kind of reflection, students step back from the learning process to think about their language learning strategies and their progress as language learner. They are able to recognize their strengths and weaknesses and they could design strategy for their learning to make better performance $(\mathrm{H}$. Andrade \& du, 2007). In this case, the young learners apply their metacognitive awareness that include students' knowledge and self-awareness that might lead to successful learning.

In off-task self-assessment, students are given opportunity to prepare their knowledge on writing paragraph and design their learning to meet the criteria. In on-task self-assessment, more opportunity is given since the students could use the self-assessment checklist throughout the process of their writing. But, they share the same purpose that is to let the students ready for the instruction and making reflection for improvement so that they are ready for the subsequent learning (Earl, 2013; Shahrakipour, 2014). Students are also given opportunity to monitor and critically reflect on their learning so that they could decide on the next step (self-reflection, self-monitoring, and self-adjustment). If the students can perform these overtime, they would be able develop their positive affective domain, such as selfconfidence (Butler \& Lee, 2010; Yoon \& Lee, 2013), motivation (Paris \& Paris, 2001; Yoon \& Lee, 2013), self-efficacy (Baleghizadeh \& Masoun, 2013; Johnson \& Gelfand, 2013), and reduce anxiety in English learning (Yoon \& Lee, 2013). Moreover, in spite of its function as metacognitive approach in learning, self-assessment is also consistent and incorporates with some other pedagogical approaches such as autonomous learning, self-directed learning, lifelong learning, and sustainable assessment.

Self-assessment place learning, reflection, and decision primarily on the learners' hands (Earl, 2013) and there is improvement on students' independency (Birjandi \& Tamjid, 2012), self-directed learning (Cameron, 2010; Carless, 2005), lifelong learning, and sustainable assessment. Self-assessment will also enhance the learners' ownership of learning since self-assessment could enhance the clarity of the objectives of learning, involve students to monitor their learning process, and facilitate opportunity of making reflection about their learning outcome (Brown \& Lee, 2015). This study does not cover the area of how these affective domains might affect or correlate with the young learners' self-assessment and writing performance. Therefore, there should be further investigation conducted in these areas.

The training sessions conducted as pre-experimental procedure in this study might allowed the young learners to familiarize themselves with the criteria of good paragraph writing, and by using self-assessment the young learners would try to make reflection on whether their paragraph has meet the criteria set since the self-assessment checklist items are in accordance with the criteria. In this kind of reflection, students step back from the learning process to think about their language learning strategies and their progress as language learner. They are able to recognize their strengths and weaknesses and they could design strategy for their learning to make better performance $(\mathrm{H}$. Andrade \& du, 2007; Butler \& Lee, 2010). In this case, the young learners apply their metacognitive awareness that include students' knowledge and self-awareness (Earl, 2013) that might lead to successful learning. The exercise of using self-assessment (either on-task and of - task) should be done frequently (Earl \& Katz, 2006). It will foster transfer of the learned skill to accomplish the writing task and develop good habit for revising that help students to write better since self-assessment 
reinforce constructive habit of keeping through on series of writing stages. This study had not provided opportunities for the young learners to practice using self-assessment in regular basis since the study was only focusing on the short-term effect of self-assessment where the effect was directly measured after the treatment was completed. Therefore, further investigation is needed in this area.

\section{CONCLUSION}

This study presented evidence that putting self-assessment in contextual (on-task) and decontextual (off-task) format bring similar effect on the young learners' writing performance. It indicates that whether the self-assessment is conducted along the stages of writing: pre-writing, drafting, revising, editing, and publishing, or only at the beginning before the young learners start their process of writing, it would bring no different on their writing performance. The similar effect was found for the short effect of self-assessment where self-assessment takes the role of assessment as learning. Therefore, for further study is suggested to investigate the long term effect of self-assessment on not only the young learners' writing performance, but also their affective domains and the pedagogical approaches in English instruction. As the consequence, a longitudinal study is suggested to be conducted. Moreover, this study has not explored how valid students assess themselves in the on-task and off-task self-assessment, how they experience their self-assessment process, what might be their challenges, and how they take the benefits of self-assessment process for their writing performance. Therefore, more in depth study should be conducted on those areas. Nonetheless, the involvement of more capable peer or adults are suggested to be included in the implementation of self-assessment since their present are assumed to be able to guide young learners' self-regulation and sense of control over their learning which take roles as integrated part in self-assessment.

\section{ACKNOWLEDGMENTS}

Sincere gratitude is addressed to the Indonesia Ministry of Research, Technology, and Higher Education for funding this study in 2018.

\section{REFERENCES}

Andrade, H., \& du, Y. (2007). Student responses to criteriareferenced self-assessment. Assessment and Evaluation in Higher Education, 32(2), 159-181. https://doi.org/10.1080/02602930600801928.

Andrade, H. G., \& Boulay, B. A. (2003). Role of rubric-referenced self-assessment in learning to write. The Journal of Educational Research, 97(1), 21-34. https://doi.org/10.1080/00220670309596625.

Baleghizadeh, S., \& Masoun, A. (2013). The Effect of Self-Assessment on EFL Learners' Self-Efficacy. TESL Canada Journal, 31(1), 42-58. http://teslcanadajournal.ca/index.php/tesl/article/view/1166.

Birjandi, P., \& Tamjid, N. H. (2012). The role of self-, peer and teacher assessment in promoting Iranian EFL learners' writing performance. Assessment and Evaluation in Higher Education, 37(5), 513-533. https://doi.org/10.1080/02602938.2010.549204.

Brown, H. D., \& Lee, H. (2015). Teaching by Principles: An Interactive Approach to Languag Pedagody. Alijafarnode. 
Butler, Y. G. (2009). How do teachers observe and evaluate elementary school students' foreign language performance? A case study from South Korea. TESOL Quarterly, 43(3), 417-444. https://doi.org/10.1002/j.1545-7249.2009.tb00243.x.

Butler, Y. G., \& Lee, J. (2006). On-Task versus Off-Task Self-Assessment among Korean Elementary School Students Studying English. The Modern Language Journal, 90(4), 506-518. https://doi.org/10.1111/j.1540-4781.2006.00463.x.

Butler, Y. G., \& Lee, J. (2010). The effects of self-assessment among young learners of English. 7(1), 5-31. https://doi.org/10.1177/0265532209346370.

Cameron, L. (2010). Teaching Language to Young Learners. Cambridge University Press.

Carless, D. (2005). Prospects for the implementation of assessment for learning. Assessment in Education: Principles, Policy and Practice, 12(1), 39-54. https://doi.org/10.1080/0969594042000333904.

Dann, R. (2012). Promoting Assessment as Learning (1st ed.). Routledge. https://doi.org/10.4324/9780203470152.

Earl, L. M. (2013). Assessment as Learning: Using Classroom Assessment to Maximize Student Learning. Corwin.

Earl, L. M., \& Katz, S. (2006). Rethinking Classroom Assessment with Purpose in Mind: Vol. 2nd ed (Issue November). Crown.

Graves, D., Tuyay, S., \& Green, J. (2004). What I've Learned from Teachers of Writing. Language Arts, 82(2), 88-94. https://search.proquest.com/openview/5b82d50a19d4eaa0f7b35211675d4d40/1?pqorigsite $=$ gscholar $\& \mathrm{cbl}=41436$.

Johnson, C., \& Gelfand, S. (2013). Self-Assessment and Writing Quality. Academic Research International, 4(4), 571-581.

Le'ger, D. de Saint. (2009). Self-Assessment of speaking skills and participation in a foreign language class. Foreign Language Annals, 42(1), 158-178. https://doi.org/10.1111/j.1944-9720.2009.01013.x.

Paris, S. G., \& Paris, A. H. (2001). Classroom applications of research on self-regulated learning. Educational Psychologist, 36(2), 89-101. https://doi.org/10.1207/S15326985EP3602_4.

Schraw, G. (1998). Promoting general metacognitive awareness. Instructional Science, 26, 113-125. https://doi.org/10.1023/A:1003044231033.

Schulz, M. M. (2009). Effective writing assessment and instruction for young english Language Learners. Early Childhood Education Journal, 37(1), 57-62. https://doi.org/10.1007/s10643-009-0317-0.

Shahrakipour, H. (2014). On the Impact of Self-Assessment on EFL Learners' Receptive Skills Performance. International Research Journal of Art \& Humanities, 40(40), 143-164. http://ejournal.ukm.my/ajtlhe/article/view/11901.

Suzuki, R. (2005). Review of " Self-esteem of Japanese College Students : Suggestions based on Research on How to Foster Their 『自信力が学生を変える： 大学生意識調査からの提言』. Language Teaching, 2(2), 71-73.

Suzuki, Y. (2015). Self-assessment of Japanese as a second language: The role of experiences in the naturalistic acquisition. Language Testing, 32(1), 63-81. https://doi.org/10.1177/0265532214541885.

Yoon, E., \& Lee, H.-K. (2013). Do Effects of Self-Assessment Differ by L2 Language Level? A Case of Korean Learners of English. Asia-Pacific Edu Res, 22(4), 731-739. https://doi.org/10.1007/s40299-013-0111-z. 